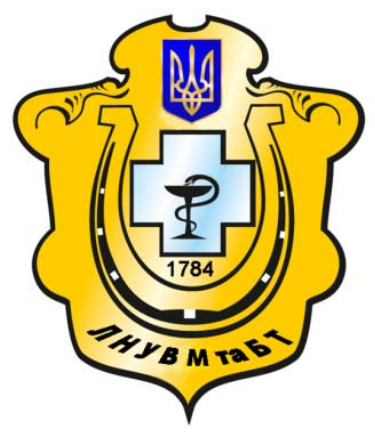

Науковий вісник Львівського національного університету ветеринарної медицини та біотехнологій імені С.3. Гжицького

Scientific Messenger of Lviv National University of Veterinary Medicine and Biotechnologies named after S.Z. Gzhytskyj

doi:10.15421/nvlvet7743

ISSN 2518-7554 print

ISSN 2518-1327 online

$\underline{\text { http://nvlvet.com.ua/ }}$

УДК 636.2:636.082

\title{
Профілактика ембріональної смертності у корів
}

\author{
М.О. Травецький, А.Й. Краєвський, Ю.В. Мусієнко \\ kay57@ukr.net, musik_ne@ukr.net \\ Сумський національний аграрний університет, \\ вул. Г. Кондратьєва, 160, м. Суми, 40021, Украӥна
}

\begin{abstract}
У статті проведено аналіз наукових даних та власних досліджень щодо вивчення та обтрунтування профілактичної ефективності кетопрофену при ембріональній смертності у корів за синхронізації еструсу залежно від тривалості періоду після родів.

Відомо, ще у корів за спонтанного відновлення статевої ииклічності після отелення за наступної ії синхронізації утворюються менші жовті тіла, хоча запліднюваність їх вища, ніж у тварин без відновлення статевої циилліності після родів перед синхронізацією еструсу. Застосування коровам з невеликими жовтими тілами нестероїдних протизапальних препаратів інгібує вироблення простагландину $F_{2 \alpha}$ слизовою оболонкою матки через блокування цииклогенази II типу.

Стимуляцію та синхронізацію статевої ичклічності проводили сурфагоном і естрофаном та на 10 день осіменяли корів. Тваринам дослідних підгруп на 11 день після осіменіння вводили у лікувальній дозі нестероїдний протизапальний препарат аініл. Профілактичне щодо ембріональної смертності застосування аінілу після осіменіння корів за попередньої синхронізаиї еструсу сприяе підвищенню запліднюваності тварин загалом на 7,3\%.

Такий вплив нестероїдних протизапальних препаратів на запліднюваність корів залежсн від періоду після отелення може вказувати на запобігання ембріональної смертності у тварин з відновленою статевою ијклічністю після родів незалежно від етіології утворення жовтого тіла за спонтанного прояву статевого изику чи синхронізаиії еструсу.

Ключові слова: ембріональна смертність, анафродизія, сурфагон, аініл, кетопрофен, естрофан, синхронізація еструсу, запліднюваність.
\end{abstract}

\section{Профилактика эмбриональной смертности у коров}

\author{
Н.А. Травецький, А.И. Краевский, Ю.В. Мусиенко \\ kay57@ukr.net,musik_ne@ukr.net \\ Сумской национальный аграрный университет, \\ ул. Г. Кондратьева, 160, г. Суми, 40021, Украина
}

\begin{abstract}
Проведен анализ научных данных и собственных исследований по изучению и обоснованию профилактической эффективности кетопрофена при эмбриональной смертности у коров при синхронизации эструса в зависимости от продолжстельности периода после родов.

Известно, что у коров при спонтанном восстановлении половой цииклчности после отела после последующей ее синхронизации образуются небольшие желтые тела, хотя оплодотворяемость их выше, чем у животных без восстановления половой цикличности после родов перед синхронизацией эструса. Применение коровам с небольшими желтыми телами нестероидных противовоспалительных препаратов ингибирует выработку простагландина $F_{2 \alpha}$ слизистой оболочкой матки из-за блокирования ичиклогеназы II типа.

Стимуляциию и синхронизацию половой ичиклиности проводили сурфагоном и естрофаном и на 10 день осеменяли коров. Животнылм опытных подгрупп на 11 день после осеменения вводили в лечебной дозе нестероидный противовоспалительный препарат аинил. Профилактическое по отночению к эмбриональной смертности применение аинила после осеменения
\end{abstract}

Citation:

Travetskyy, M.O., Krajewski, A.Y., Musienko, Y.V. (2017). Prevention of embryonic mortality in cattle. Scientific Messenger LNUVMBT named after S.Z. Gzhytskyj, 19(77), 200-203. 
коров при предварительной синхронизачии эструса способствует повышению оплодотворяемости животных в среднем на $7,3 \%$.

Такое влияние нестероидных противовоспалительных препаратов на фертильность коров в зависимости от периода после отела может указывать на предупреждение эмбриональной смертности у животных с восстановленной половой цикличностью после родов независимо от этиологии образования желтого тела при спонтанном проявлении полового ичикла или синхронизации эструса.

Ключевье слова: эмбриональная смертность, анафродизия, сурфагон, аинил, кетопрофен, естрофан, синхронизация эструса, оплодотворяемость.

\title{
Prevention of embryonic mortality in cattle
}

\author{
M.O. Travetskyy, A.Y. Krajewski, Y.V. Musienko \\ kay57@ukr.net,musik_ne@ukr.net \\ Sumy National Agrarian University, \\ G. Kondratyev str., 160, Sumy, 40021, Ukraine
}

\begin{abstract}
The article analyzes the scientific data and own research on study and formulation the preventive efficacy of ketoprofen during embryonic mortality in cows for estrus synchronization, depending on the duration of the period after birth.

It is known that in cows at spontaneous recovery of sexual cyclicity after calving for its next synchronization form smaller corpus luteum, although their fertilization is higher than in animals without sexual cyclical recovery after giving birth to synchronize estrus. The application for cows with small yellow bodies of NSAIDs inhibit the production of prostaglandin F2 $\alpha$ by uterine lining through blocking Cyclogenesis of type II.

Stimulation and sexual cyclical synchronization was performed using surfagon and estrofan and at the 10th day cows were inseminated. Animals of the experimental subgroups at the 11th day after insemination were injected in therapeutic dose NSAIDs ainil. The prophylactic use of ainil towards embryonic mortality after insemination of cows for previous estrus synchronization promotes animal insemination by average of $7.3 \%$.

Such effect of NSAIDs on cows fertilization depending on the period after calving can point to the prevention of fetal death in animals with restored sex cycles after calving regardless the cause of the formation of the corpus luteum at spontaneous manifestation of the sexual cycle or estrus synchronization.
\end{abstract}

Key words: embryonic mortality, anaphrodisia, surfahon, ainil, ketoprofen, estrofan, synchronization of estrus, fertilization.

\section{Вступ}

Зниження репродуктивної функції високопродуктивних корів відбувається через недосконалість методики виявлення оптимального часу осіменіння тварин, значне поширення і тривалу відсутності статевої циклічності або ії субклінічний перебіг після отелення, низьку запліднюваність, ембріональну смертність, високу молочну продуктивність (Diskin et al., 2011). Низька запліднюваність і повторний прояв статевого циклу без зміни його тривалості $є$ непрямою ознакою ранньої ембріональної смертності на 8-16 добу після осіменіння (Sreenan and Diskin, 1986). Відсутність вагітності і прояв статевої циклічності через 1,52 місяці після осіменіння свідчить про ембріональну смертність більш пізнього періоду, яку можна виявити за проведення сонографічної діагностики вагітності на 30-32 і повторно на 60-90 добу після осіменіння (Krajewskiy and Kurguz, 2011).

Ембріональна смертність $є$ однією 3 важливих причин зниження репродуктивної функції у корів. Ембріональні втрати в перший критичний період розвитку ембріона на 8-16 добу після осіменіння можуть бути пов'язані 3 розладом матковоембріонального зв'язку (Роре, 1988; Rhinehart et al., 2009; Pohler et al., 2012). Порушення матковоембріонального зв'язку відбувається внаслідок передчасної секреції слизовою оболонкою матки простагландину $\mathrm{F}_{2}$ альфа $\left(\mathrm{PGF}_{2 \alpha}\right)$ (Thatcher et al., 2001), а також затримки або недостатнього виробництва IFN-тау ембріоном (Demmers et al., 2001). В результаті цього відбувається затримка або несприйняття сигналу про присутність ембріона у матці, що призводить до ембріональної смертності, особливо за наявності будьякого стресу, зокрема теплового. Виробництво активних форм кисню $є$ важливою причиною підвищеної ембріональної смертності (Sakatani et al., 2008). Негативний енергетичний баланс впливає на розвиток фолікулів, ріст та якість ооцитів. Усі ці недоліки призводять до порушення розвитку ембріонів, що є ще однією важливою причиною ембріональної смертності. Негативний енергетичний баланс впливає на мікросередовище розвитку і дозрівання яйцеклітин, що призводить до утворення незрілого ооцита. Крім того, при негативному енергетичному балансі зменшується у крові концентрація прогестерону, знижується рівень інсуліноподібного фактора росту, що призводить до порушення мікросередовища матки, тим самим спричиняє високу ембріональну смертність (Leroy et al., 2008).

Використання нестероїдних протизапальних препаратів у ветеринарному акушерстві та гінекології (Richards et al., 2009; Laven et al., 2012), захворюваннях молочної залози (Suojala et al., 2010), трансплантації ембріонів (Scenna et al., 2005; Guzeloglu et al., 2007; Geary et al., 2010), хірургічній практиці (Whay et al., 2005; Flower et al., 2008; Duffield et al., 2010; Newby et al., 2014) описані багатьма дослідниками. Нестероїдні протизапальні препарати (НПЗП) володіють протизапальною, знеболювальною та жарознижувальною дією за допомогою інгібування циклооксигенази (ЦОГ), зокрема ферменту ЦОГ-2, який відіг- 
рає головну роль в синтезі простагландинів (PG) (Cashman, 1996; Brideau et al., 2001). Одним із сучасних нестероїдних протизапальних засобів, доступних в Україні, що рекомендують для лікування корів, $\epsilon$ кетопрофен.

Експериментальні дослідження щодо використання нестероїдних протизапальних препаратів з метою профілактики ембріональної смертності у корів описані багатьма дослідниками, проте їхні дані суперечливі. Тому метою наших досліджень було визначити профілактичну ефективність кетопрофену при ембріональній смертності у корів за синхронізації еструсу залежно від тривалості періоду після родів.

\section{Матеріал і методи досліджень}

Перед синхронізацією еструсу всіх корів розділили на дві групи залежно від тривалості періоду від отелення до діагностичного етапу гінекологічної диспансеризації. У першу групу ввійшли тварини 3 тривалістю періоду після отелення до 90 днів, у другу 91 і більше днів. Перед стимуляцією та синхронізацією статевої циклічності проводили діагностичний етап гінекологічної диспансеризації корів з використанням трансректального сонографічного дослідження стану матки та яєчників за допомогою ультразвукового сканера CTS-800.

У першу групу входили в основному корови із антральними фолікулами різних розмірів у яєчниках, жовті тіла зустрічалися рідко та були невеликих розмірів, що вказує на гальмування статевої циклічності (анафродизію) внаслідок гіпофункціонального стану яєчників. В цю ж групу входили корови без антральних фолікулів, що є ознакою повної гіпофункції яєчників.

Всіх корів з функціонально активними яєчниками відносили до другої групи. У цих тварин матка реагу- вала на масаж, а в яєчниках виявляли жовте тіло та різні за розмірами антральні фолікули, що вказує на відновлення статевої циклічності після отелення та функціонально активний стан яєчників під час гінекологічного дослідження. Варто зазначити, що серед цих корів були тварини після попередньої синхронізації.

У тварин обох груп проводили стимуляцію та синхронізацію статевої циклічності за протоколом «овсінх», який включав таку схему: нульовий день сурфагон 10 мл; 7-й день - естрофан 2 мл, 9-й день сурфагон 5 мл; на 10 день осіменяли один раз вранці. Препарати вводили в один і той же час ввечері. Потім корів обох груп розділили на дві підгрупи, дослідну і контрольну. Тваринам дослідних підгруп на 11 день після осіменіння вводили у лікувальній дозі нестероїдний протизапальний препарат аініл (діюча речовина кетопрофен). На 32-37 добу проводили діагностику вагітності за допомогою ультразвукового сканера CTS-800. За результатами діагностики вагітності у корів визначали їх запліднюваність і проводили аналіз профілактичної ефективності препарату відносно ембріональної смертності. Результати досліджень опрацьовані статистично 3 урахуванням критерію Стьюдента.

\section{Результати та їх обговорення}

Одержані результати досліджень свідчать, що застосування аінілу (діюча речовина кетопрофен) у лікувальній дозі на 11 добу після осіменіння корів, за попередньої синхронізації еструсу, сприяє вірогідному $(\mathrm{P}>0,05)$ підвищенню запліднюваності тварин загалом на 7,3\% (рис. 1), що вказує на його профілактичну ефективність щодо ембріональної смертності.

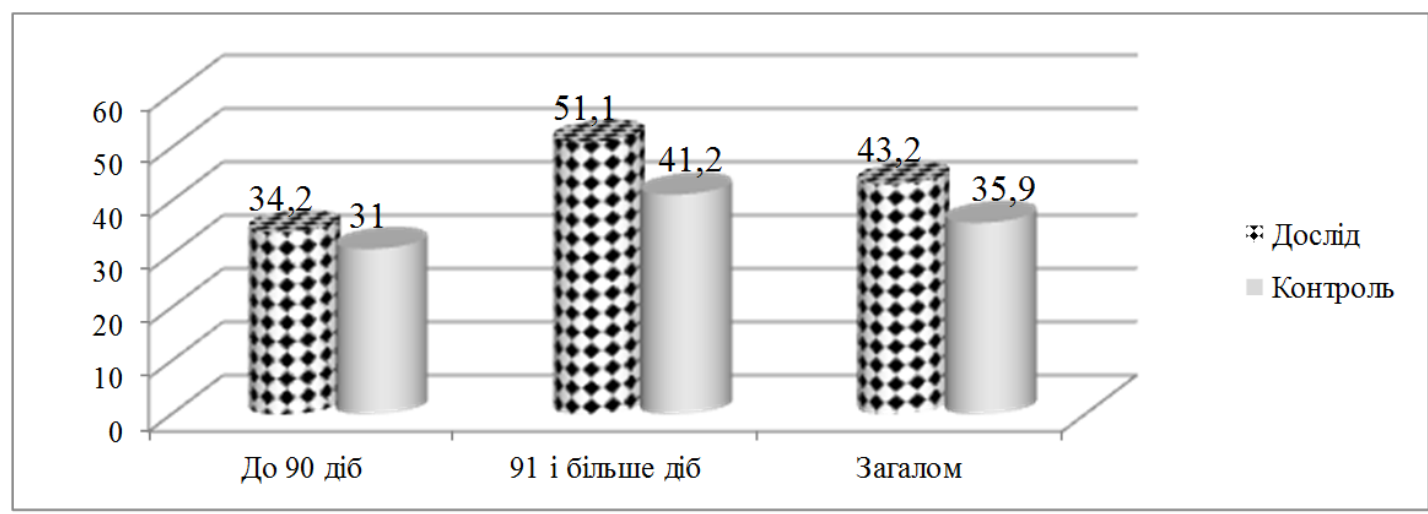

Рис. 1. Запліднюваність корів у дослідній і контрольній групах залежно від терміну проведення синхронізації еструсу після отелення

Проте проведення детального аналізу результатів досліджень показало, що в корів, у яких ще не відновилась статева циклічність і синхронізацію еструсу проводили до 90 доби після отелення, запліднюваність у дослідній і контрольній підгрупах майже не відрізнялась. Водночас за синхронізації еструсу в корів через 91-у і більше діб, у яких вже відновилась статева циклічність i/або проводилась синхронізація еструсу, за наступного іiі проведення запліднюваність у піддослідній групі тварин вірогідно $(\mathrm{P}>0,05)$ підвищувалась майже на $10 \%$.

\section{Висновки}

Відомо, що у корів за спонтанного відновлення статевої циклічності після отелення за подальшої іiі 
синхронізації утворюються менші жовті тіла, хоча запліднюваність їх вища, ніж у тварин без відновлення статевої циклічності після родів перед синхронізацією еструсу. Застосування коровам 3 невеликими жовтими тілами нестероїдних протизапальних препаратів інгібує вироблення простагландину $\mathrm{F}_{2 \alpha}$ слизовою оболонкою матки через блокування циклогенази II типу.

Такий вплив нестероїдних протизапальних препаратів на запліднюваність корів залежно від періоду після отелення може вказувати на запобігання ембріональної смертності у тварин з відновленою статевою циклічністю після родів незалежно від етіології утворення жовтого тіла за спонтанного прояву статевого циклу чи синхронізації еструсу.

\section{Бібліографічні посилання}

Diskin, M.G., Parr, M.H., Morris, D.G. (2011). Embryo death in cattle: an update. Reprod Fertil Dev. 24(1), 244-251.

Sreenan, J.M., Diskin, M.G. (1986). The extent and timing of embryonic mortality in the cow. Embryonic mortality in farm animals. Dordrech: Martinus Nijhoff, 1-11.

Krajewskiy, A.Y., Kurguz, M.M. (2011). Chastota subklinichnyh abortiv u koriv zalezhno vid stanu statevyh organiv pered osimeninnjam. Visnyk Sumskogo NAU. 2(29), 114-116 (in Ukrainian).

Pope, W.F. (1988). Uterine asynchrony: a cause of embryonic loss. Biol Reprod. 39, 799-1003.

Rhinehart, J.D., Starbuck-Clemmer, M.J., Flores, J.A., Milvae, R.A., Yao, J., Poole, D.H. (2009). Low peripheral progesterone and late embryonic/early fetal loss in suckled beef and lactating dairy cows. Theriogenology. 71(3), 480-490.

Pohler, K.G., Geary, T.W., Atkins, J.A., Perry, G.A., Jinks, E.M., Smith, M.F. (2012). Follicular determinants of pregnancy establishment and maintenance. Cell Tissue Res. 349(3), 649-664.

Thatcher, W.W., Guzeloglu, A., Mattos, R., Binelli, M., Hansen, T.R., Pru, J.K. (2001). Uterine-conceptus interactions and reproductive failure in cattle. Theriogenology. 56, 1435-1450.

Demmers, K.J., Derecka, K., Flint, A. (2001). Trophoblast interferon and pregnancy. Reproduction. 121, 41-49.

Sakatani, M., Yamanaka, K., Kobayashi, S., Takahashi, M. (2008). Heat shock-derived reactive oxygen species induce embryonic mortality in in vitro early stage bovine embryos. J Reprod Dev. 54(6), 496-501.

Leroy, J.L., Opsomer, G., Van Soom, A., Goovaerts, I.G., Bols, P.E. (2008). Reduced fertility in high-yielding dairy cows: are the oocyte and embryo in danger? The importance of negative energy balance and altered corpus luteum function to the reduction of oocyte and embryo quality in high-yielding dairy cows. Reprod Domest Anim. 43(5), 612-622.

Richards, B.D., Black, D.H., Christley, R.M. (2009). Effects of the administration of ketoprofen at parturition on the milk yield and fertility of Holstein-Friesian cattle. Vet. Rec. 165(4), 102-106.

Laven, R., Chambers, P., Stafford, K. (2012). Using nonsteroidal anti-inflammatory drugs around calving: maximizing comfort, productivity and fertility. Veterinary Journal. 192(1), 8-12.

Suojala, L., Simojoki, H., Mustonen, K. (2010). Efficacy of enrofloxacin in the treatment of naturally occurring acute clinical Escherichia coli mastitis. Journal of Dairy Science. 93(5), 1960-1969.

Scenna, F.N., Hockett, M.E., Towns, T.M., Saxton, A.M., Rohrbach, N.R., Wehrman, M.E. (2005). Influence of a prostaglandin synthesis inhibitor administered at embryo transfer on pregnancy rates of recipient cows. Prostaglandins Other Lipid Mediat. 78, 38-45. doi: 14.1016/j.prostaglandins.2005.02.003.

Guzeloglu, A., Erdem, H., Saribay, M., Thatcher, W., Tekeli, T. (2007). Effect of the administration of flunixin meglumine on pregnancy rates in Holstein heifers. Vet Rec. 160, 404-406 doi: 10.1136/vr.160.12.404.

Geary, T.W., Ansotegui, R.P., MacNeil, M.D., Roberts, A.J., Waterman, R.C. (2010). Effects of flunixin meglumine on pregnancy establishment in beef cattle. J Anim Sci. 88, 943-949 doi: 10.2527/jas.2009-2087.

Duffield, T.F., Heinrich, A., Millman, S.T. (2010). Reduction in pain response by combined use of local lidocaine anesthesia and systemic ketoprofen in dairy calves dehorned by heat cauterization. Canadian Veterinary Journal. 51(3), 283-288.

Newby, N.C., Pearl, D.L., Tucker, C.B. (2014). An investigation of the effects of ketoprofen following rumen fistulation surgery in lactating dairy cows. Canadian Veterinary Journal. 55(5), 442-448.

Flower, F.C., Sedlbauer, M., Carter, E. (2008). Analgesics improve the gait of lame dairy cattle. Journal of Dairy Science. 91(8), 3010-3014.

Whay, H.R., Webster, A.J., Waterman-Pearson, A.E. (2005). Role of ketoprofen in the modulation of hyperalgesia associated with lameness in dairy cattle. The Veterinary Record Journal. 157(23), 729-733.

Brideau, C., Van Staden, C., Chan, C.C. (2001). In vitro effects of cyclooxygenase inhibitors in whole blood of horses, dogs, and cats. Am. J. Vet. Res. 62, 17551760. doi: 10.2460/ajvr.2001.62.1755.

Cashman, J. (1996). The mechanisms of action of NSAIDs in analgesia. Drugs. 52, 13-23 doi: 10.2165/00003495-199600525-00004.

Стаття надійшла до редакиії 30.03.2017 